\title{
ZCCHC8 wt Allele
}

National Cancer Institute

\section{Source}

National Cancer Institute. ZCCHC8 wt Allele. NCI Thesaurus. Code C122879.

Human ZCCHC8 wild-type allele is located in the vicinity of 12 q24.31 and is approximately $29 \mathrm{~kb}$ in length. This allele, which encodes zinc finger CCHC domain-containing protein 8, may be involved in RNA binding and splicing. 